\title{
注射針の强度試驗法の研究
}

\section{Our Test on the strength of Injection Needles}

\author{
科 學 研、究 所
}

Scientific Research Institute Co., Ltd.

$\begin{array}{lllll}\text { 谷 } & \text { 口 } & \text { 和 } & \text { 雄 } & \text { Kazuo Taniguchi } \\ \text { 藤 } & \text { 原 } & \text { 淸 } & \text { 壽 } & \text { Kiyohisa Fujiwara }\end{array}$

\section{I 緒 言}

注射針管部の強度については，まだ明確な定義がな く，その内容は漠然としている，それ故に，製造者は 注射針を折り曲げて経験的にその良否を判断してい る. われわれは注射針の強度を科学的に定義して，そ れを定量的に測定する方泆を研究した。

注射針管部の強度は次の両性質に分けて考元らる。

$\mathrm{a}$, 曲り難い事, 即ち剛性の強い事

b，折れ難い事，即ら勒性の高い事

実際には曲り難くすれば折れ易くなり，反対に折れ難 くすると曲り易くなる。

これらの両性質を如何に調和するかが注射針製造上重 要なことである.

注射針管部に特殊な曲げ試験を行つてその強度を試 験する事にした。

\section{- II 曲げ試驗法}

(a) 曲げ試験法

第 1 図に示す様に初め $A B$ に垂直な $P$ 方向に荷重 を働かせ，注射針が曲るに従つて常に重荷点 B' の接 線に垂直な P' 方向に荷重を加える。

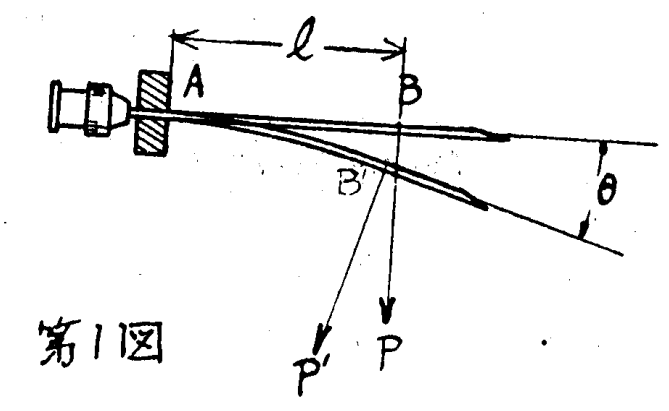

この様にして管部か破断するまで，遂次荷重を加え

- て, その引張力 $\mathrm{P}$ と荷重点の振れ角 $\theta$ との関係, 即ち

P. $\theta$ 曲線を求める.

弾性限界内では次の関係式が近似的に成立する.

$\frac{\mathrm{P}}{\theta}-\frac{2 \mathrm{EJ}}{l^{2}}$
但し $\theta$; 荷重点の振れ角
$P$; 荷重
$l ;$ 片持の長さ
$\mathrm{E} ;$ ヤング率
I; 断面の慣性モーメント

管に対しては

$$
\begin{array}{r}
I-\frac{\pi}{64}\left(D^{4}-d^{4}\right) \text { 但し } \mathrm{D} ; \text { 外径 } \\
\mathrm{d} ; \text { 内径 }
\end{array}
$$

であり. 更に片持ちの長さを外径の二乗に比例して取 る様にすると，

即ち， $l=\mathrm{KD}^{2}$ とおくと，

(1) 式は次の様になる.

$$
\begin{aligned}
& \frac{\mathrm{P}}{\theta}-\frac{\pi \mathrm{E}}{32 \mathrm{~K}^{2}}\left(1-\frac{\mathrm{d}^{4}}{\mathrm{D}^{4}}\right) \\
& \therefore \frac{\mathrm{P}}{\theta}-\mathrm{C}\left(1-\frac{\mathrm{d}^{4}}{\mathrm{D}^{4}}\right) \mathrm{E}
\end{aligned}
$$

$$
\text { 但乙 } \mathrm{C}-\frac{\pi}{32 \times \mathrm{K}^{2}}
$$

上式より $\frac{\mathrm{d}}{\mathrm{D}}$ が一定の場合は，弾性限界内に於て同一材 質について考えると $\frac{\mathrm{P}}{\boldsymbol{\theta}}$ は一定になる事を示している.

(b) 㓮性と性

上述の曲げ試験により支点 Aに於けるモーメントM $-\mathrm{P} \cdot l$ を計算してM一曲線を作る.（第 3 因）

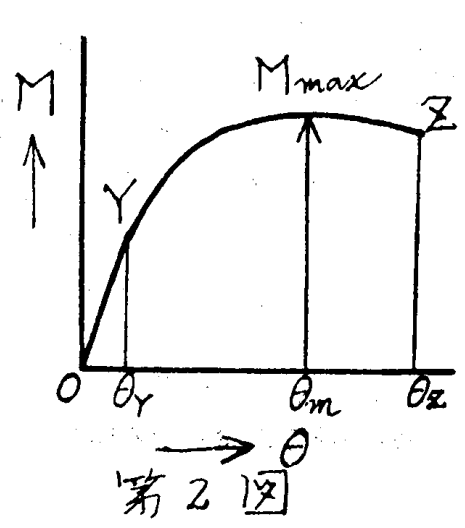

モーメントの最大値 $\mathrm{M}$ max が大きい程, 剛性が大きい（曲り 難い)のである. また，曲代試験によ り，荷電 Pが管部を 破断するまでに為し た仕事量の総和 W を求める。そこのWの 大きい程靱性が高い

（折れ難い）のである.最大モーメント

$\mathrm{M} \max =\mathrm{P} \max \times \mathbf{l}$ 
荷重の為した総仕事量は, 第 2 四の $\theta$ 軸, 曲線oz; 直 線 $\boldsymbol{z} \theta_{\mathbf{z}}$ 囲さ面積で表わされるから，

$$
\mathrm{W}=\int_{0}^{\theta_{z}} \mathrm{M} \mathrm{d} \theta=\int_{0}^{\theta z} \mathrm{P} l \mathrm{~d} \theta
$$

$\mathrm{M}$ 一 $\theta$ 曲線を求める代りに $\mathrm{P}$ - $\theta$ 曲線を作り, 近似的に

$\mathrm{P}$ max を以て剛性を表わし P- $\theta$ 曲線の囲む面積を求め て勒性を表わすことが出来る.しかし実用上の点から， $\theta$ は $0^{\circ}$ から $90^{\circ}$ まで変化するるのとし，此の間の仕事 量W $\frac{\pi}{2}$ を以て靬性を示す事にする.

\section{I 曲げ試驗器}

上記の方法による曲げ試験器を設計製作した（科研 特許権所用, 細材の曲げ試験装置, Pat: No, 190106) その写真及び第 4 図について構造を説明する.

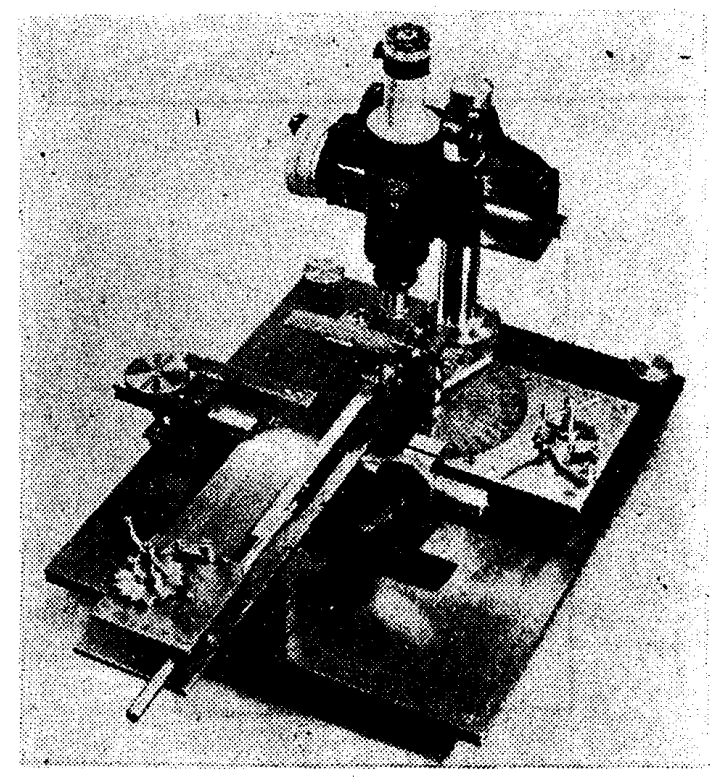

(a) 試料保持部

Bの台上にのつている部分で, コレットチャッック Aは 試料を保持すると同時にハンドルCによつて回転し， 振れ角 $\theta$ を与える.チャックは $0.3 \mathrm{~mm}$ から $1.4 \mathrm{~mm}$ 径 の物を保持出来る. また $\theta$ は10間隔で任意の所湢定 出来る.

（b）荷重部
Dの台上にのつている部分で，E の切欠部に試料を引

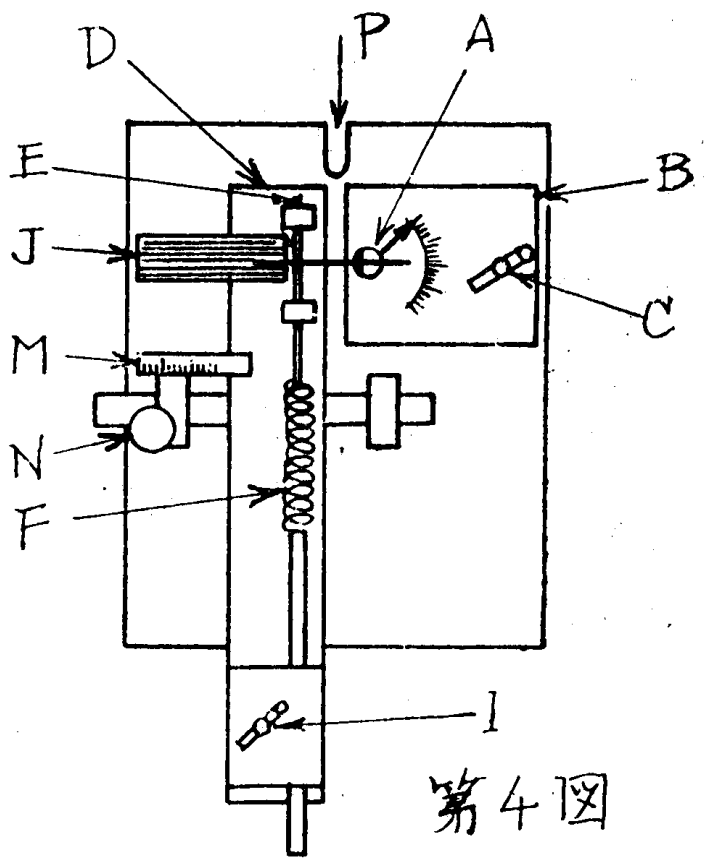

つかけて，ハンドルIを回転しバネ程 Fによつて試料 に荷重をかける. 自由端の平行は平行目盛了に体つて 見る.（バネ拜は注射針の太さの管に対して0〜1kgの わので十分である。)

(C) 片持長さ指示部

荷重部全体は握り Nを回転すると左右に移動して, 片持長さの調節が出来る. 此の片持長さは副尺付目盛 Mで測る.試作品では $3.2 \mathrm{~mm}$ から53mmに調節出来る.

（d）顕微鏡

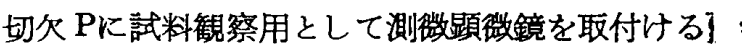
事が出来る(写真は其取付けた状態を示す)

\section{III 驗}

前述の試験器を使用して，注射針及びその素管につ いて，測定した結果を次に述へる。

以下, 片持長さは (2) 式に於ける $l=\mathrm{KD} 2$ はK -25 としてmm単位で計算してある.

(a) 一般注射針の強度

\begin{tabular}{|c|c|c|c|c|c|c|c|c|c|}
\hline No; & 用 途 & $\begin{array}{r}\text { 外 堡 } \\
(\mathrm{mm})\end{array}$ & $\begin{array}{c}\text { 厚 } \\
(\mathrm{mm})\end{array}$ & 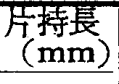 & $\begin{array}{c}\operatorname{Pmax} \\
(\mathrm{gr})\end{array}$ & $\begin{array}{c}\operatorname{Mmax} \\
(\mathrm{gr}-\mathrm{cm})\end{array}$ & 破断 & $\mathrm{W}_{\frac{\pi}{2}}(\mathrm{gr} \cdot \mathrm{cm})$ & 備 考 \\
\hline N,o. 1 & 皮下 & 0.40 & 0.08 & 4.00 & 375 & 150 & $80^{\circ}$ & 175 & 1 社 \\
\hline 2 & $\prime \prime$ & 0.42 & 0.08 & 4.40 & 360 & 159 & $80^{\circ}$ & 191 & 口 \\
\hline 3 & "I & 0.49 & 0.08 & 6.00 & 370 & 222 & $35^{\circ}$ & 97 & "l \\
\hline 4 & "l & 0.50 & 0.14 & 6.25 & 570 & 356 & $90^{\circ}$ 以上 & 478 & B-D 社 \\
\hline 5 & 静 脈 & 0.55 & 0.12 & 7.60 & 570 & 430 & $90^{\circ}$ 以上 & 580 & $" 1$ \\
\hline 6 & "I & 0.60 & 0.12 & 9.00 & 450 & 405 & $40^{\circ}$ & 184 & 八社 \\
\hline 7 & $" \prime$ & 0.69 & 0.11 & 11.90 & 420 & 500 & $70^{\circ}$ & 443 & 口 社 \\
\hline 8 & " & 0.70 & 0.13 & 12.20 & 570 & 690 & $90^{\circ}$ 以上 & 890 & 1 社 \\
\hline 9 & 筋 肉 & 0.80 & 0.10 & 16.00 & 560 & 895 & $60^{\circ}$ & 618 & 口 杜 \\
\hline
\end{tabular}

第 1 表 一般注射針強度 
一般菜局で購入した数種の国座注射針（イ，ロ，及ひび 一社製作のもの)，及び米国B-D社製の注射針二種の 強度を第 1 表に示す，国库針と B-D 針を比較した場 合, $\mathrm{P} \max (\mathrm{M} \max )$ は国屎針が B-D 針の60 70\%, 又W $\frac{\pi}{2}$ はB-D針の $20 〜 30 \%$ 程度の值を示している,

即ち，一般国産注射針は B-D注射針に比して，相当 に強度が低い，特試験中 $40^{\circ}$ 程度で折れるすのああ つて，畩性は著しく劣つている，これは肉厚の不足が 大きな原因になつていると考えられる。

(b) 試作往射針の強度
勒性は $1 \mathrm{~mm}$ 弱の所海大の点がある. 寒際製作する 場合には，作業工程等との都合もあるが, $1 \mathrm{~mm}$ 前後で 最終烧鈍を行うのが，強度上適当であることが判る. しかし加工硬化の程度は材質, 焼鈍温度及び加工条件 等认估つて，変化し易いから，常に検査を行つて最良 の点を保つ様に注意しなければならない。

上述の様な注意をしても, 向且つ強度全般が不足の 場合は，外径一定とすれば，肉厚を増加しなければなら ない，外径 $0.49 \mathrm{~mm}$ の注射針の肉厚を $0.09 \mathrm{~mm}, 0.11 \mathrm{~m}$ $\mathrm{m}, 0.13 \mathrm{~mm}$ の三種類に変へて㓮性と靯性が増加する

\begin{tabular}{|c|c|c|c|c|c|c|c|c|c|c|c|}
\hline \multirow{2}{*}{\multicolumn{2}{|c|}{ No; }} & \multirow{2}{*}{$\begin{array}{c}\text { 焼鉠 } \\
\text { 琶m) }\end{array}$} & \multirow{2}{*}{$\begin{array}{c}\text { 焼，鍍 } \\
\text { 温 } \\
\text { (oe) }\end{array}$} & \multicolumn{2}{|c|}{ 仕上品 (mm) } & \multirow{2}{*}{$\begin{array}{l}\text { 片持長 } \\
(\mathbf{m m})\end{array}$} & \multirow{2}{*}{$\underset{(g r)}{P \max }$} & \multirow{2}{*}{$\begin{array}{c}\mathrm{Mmax} \\
(\mathrm{gr}-\mathrm{cm})\end{array}$} & \multirow{2}{*}{$\begin{array}{c}\text { 破断角 } \\
\text { (0) }\end{array}$} & \multirow{2}{*}{$\begin{array}{c}W \frac{\pi}{2} \\
(\mathrm{gr}-\mathrm{cm})\end{array}$} & \multirow{2}{*}{ 備 考 } \\
\hline & & & & 外 径 & 肉 㕌 & & & & & & \\
\hline \multirow[t]{4}{*}{ No. } & 1 & 1.4 & 1.050 & 0.45 & 0.09 & 5.06 & 450 & 223 & 50 & 155 & \\
\hline & 2 & 1.2 & " & $" \prime$ & "l & $" \prime$ & 420 & 202 & 70 & 212 & \\
\hline & 3 & 1.0 & $" \prime$ & $" \prime$ & "I & $" \prime$ & 400 & 198 & 90 上上. & 263 & \\
\hline & 4 & 0.8 & " & " & $" \prime$ & " & 390 & 193 & 90以上 & 255 & \\
\hline
\end{tabular}

第 2 表 最終焼㜢位置と強度

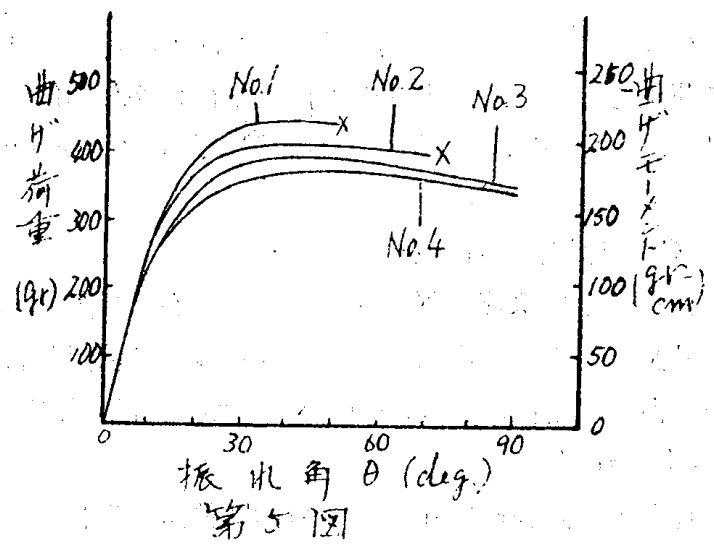

注射針管部の材質は普通 18-8 不銹鍶である。此の 鋂は焼入によつて，硬化する性質が無いので冷間加工 によつて必要な硬度を与一剛性を強めるが，冷間加工 を行えば勒性は低くなるので焼鈍によつて靶性を回復 させるのである，従つて適当な剛性と靶性を注射針に 与へるために最も都合のよい冷間加工の程度があるこ とになる。

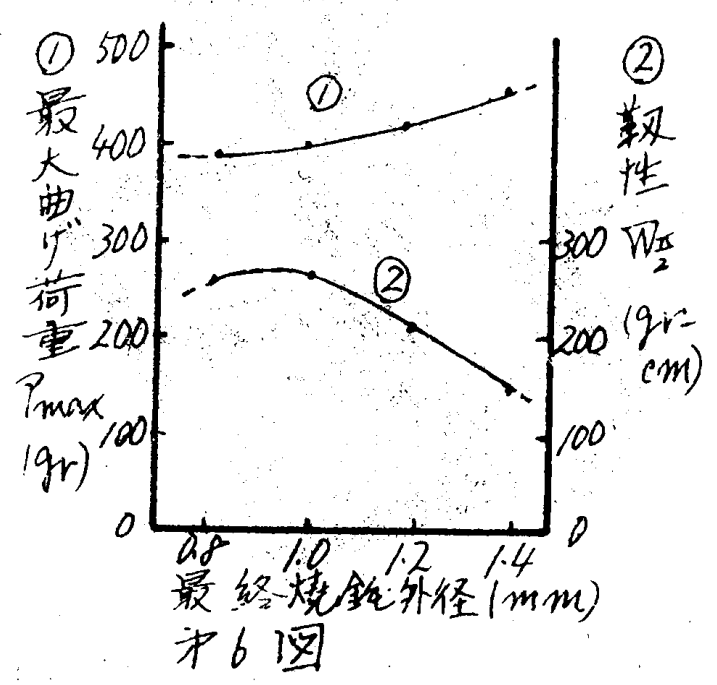

奏験結果を第 3 表に示与・之では内经少次第に小さく なるから限度がある。

以上の点に留意して試作した注射䣄の強度を第 4 表 及攵び第 7 図に示す．此の注射針の肉厚悌 1 表の国库

\begin{tabular}{|c|c|c|c|c|c|c|c|c|c|c|}
\hline \multirow[t]{2}{*}{ No; } & \multirow{2}{*}{ 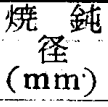 } & \multirow{2}{*}{ 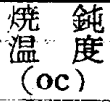 } & \multicolumn{2}{|c|}{ 代上品 (mm) } & \multirow{2}{*}{$\begin{array}{l}\text { 片持辰 } \\
(\text { mim })\end{array}$} & \multirow{2}{*}{$\underset{(\mathrm{gr})}{\mathrm{Pmax}}$} & \multirow{2}{*}{$\underset{(\mathrm{gr}-\mathrm{cm})}{\mathrm{Mmax}}$} & \multirow{2}{*}{ 破断角 } & \multirow{2}{*}{$\begin{array}{c}\mathrm{W} \frac{\pi}{2} \\
(\mathrm{gr}-\mathrm{cm})\end{array}$} & \multirow{2}{*}{ 備 考 } \\
\hline & & & 外 佳 & 内 径 & & & & & & \\
\hline No. 1 & 1.1 & 1.050 & 0.49 & 0.09 & 5.75 & 440 & 253 & $90^{\circ}$ 以上 & 343 & \\
\hline 2 & " & " & $n$ & 0.11 & " & 490 & 284 & " & 379 & \\
\hline 3 & $" !$ & $\prime \prime$ & "I & 0.13 & "I & 560 & 322 & "I & 433 & \\
\hline
\end{tabular}

第3 表 肉厚を変化した場合の強度

外圣 0.45mmの注射針を製作するのに剛性と勒性を

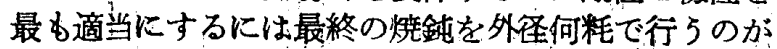
良いかを試験した結果を示す.（第2表、第5图，第6园）

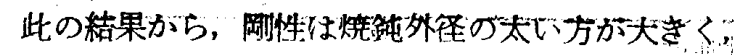

針と B-D針の中間の值をとつてある：穴の強度す又 此の両者の中間にあるが，鞁性值W $\frac{\pi}{2}$ は非常に向上 してい。 


\begin{tabular}{|c|c|c|c|c|c|c|c|c|}
\hline 用 途 & $\begin{array}{l}\text { 外 徍 } \\
(\mathrm{mm})\end{array}$ & 肉厚 & $\begin{array}{l}\text { 片持長 } \\
\text { (mm) }\end{array}$ & $\underset{(\mathrm{gr})}{\operatorname{Pmax}}$ & $\underset{\text { (gr-cm) }}{\operatorname{Mmax}}$ & $\begin{array}{c}\text { 破断角 } \\
\text { (9) }\end{array}$ & $\begin{array}{c}W \frac{\pi}{2} \\
(g r-c m)\end{array}$ & 備 洘 \\
\hline 皮下 & 0.39 & 0.09 & 3.45 & 380 & 133 & $90^{\circ}$ 以上 & 182 & \\
\hline " & 0.48 & 0.10 & 5.75 & 440 & 253 & " & 342 & \\
\hline 静 㟲 & 0.58 & 0.12 & 8.45 & 510 & 432 & $n$ & 560 & \\
\hline " & 0.69 & 0.13 & 11.80 & 590 & 697 & $80^{\circ}$ & 850 & \\
\hline 筋 肉 & 082 & C. 14 & 16.80 & 580 & 975 & $90^{\circ}$ 以上 & 1.310 & \\
\hline$" 1$ & 088 & 9,14 & 19.35 & 590 & 1.140 & $" I$ & 1.510 & \\
\hline
\end{tabular}

第 4 表，試作注射針の強度

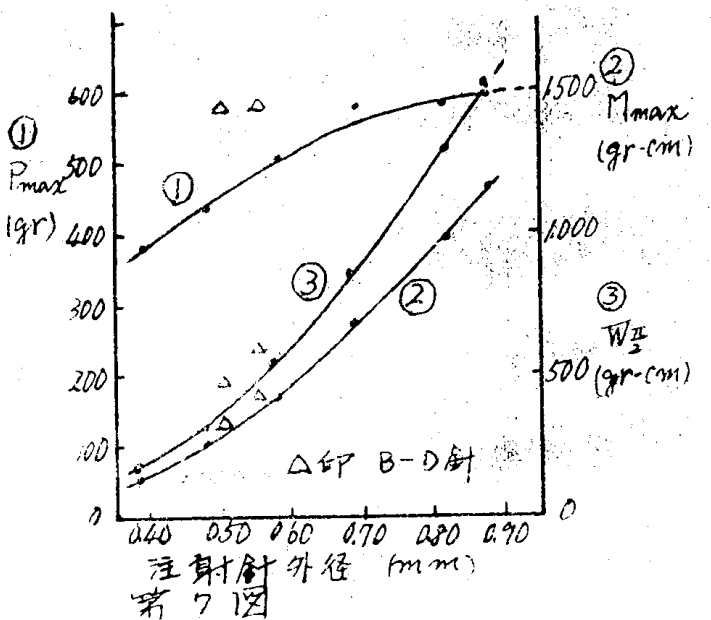

第 1 表の打販品中でも, No, 1 乙久ひひNo. 8 等は第 4 丧 に此較して，係色の無い强度を示している事央から， 此の試作注射針程度の強度は，一般国迶注射針子少し の注意に侩つて，容易に達せられるものと思われる。

\section{$V$ 結 震}

以上綜合して

(1) 注射針管部は強度上䦦性及び鞀性の二性質が必 要である。

(2) 此の強度を特殊の曲げ試験法による験試器を製 作して測定した。
(3) 風性は曲げ試騃の $\mathrm{M}-\theta$ 曲線の最大曲げモーメ ントで，又鞍性は破断まで振れ角を増加する間に荷重 のする仕事量で颁される.

(4) 各種注射針を測定して，強度に関して実用的な 数徝を出方事加出来た。

(5) 国库注射針は外国注射針に比して，一般に强度 は不足であるが，特に折れ易い欠点がある.

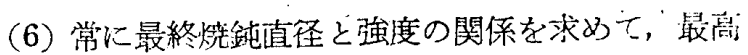
の強度を得る様に冾間加工の程度を洼定しなけれい゙な らない.

(7)国座注射針は强度確保のため，現在より10\%程 变の肉厚増加は是非必要である。

以上の判断はすべて製造者の立場から行つたもので 出つて，注射針使用者即ち医師及び患者の意見は入一 ていない、今後は染際使用する人々の意見老参考にし て，更に進展させたいと考光ている。

終りに臨み，御指導戴いた東大教授大越䛨博士，文 び福井伸二博士に御礼申上げます. 又日本医科器械学 会々長大梘菊雄博士より御支援と御鞭澾を賜わつた事 を感謝致します。

本研究は昭和26年厚生省科学研究補助金之科学研究 所注射針研究費によつて実施したるので，こ〉に謝意 を表します。

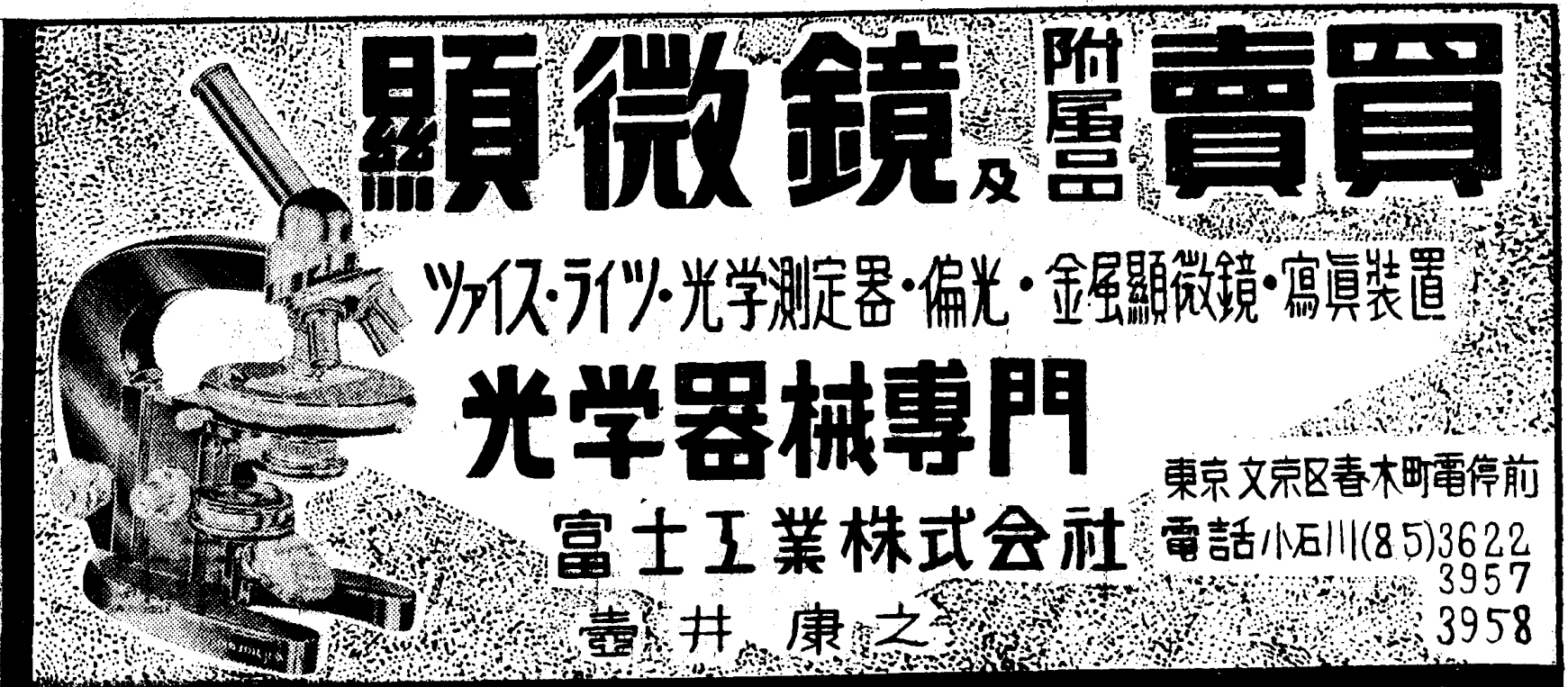

